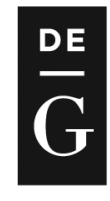

\title{
Maximising available resources: Equality and human rights proofing Irish fiscal policy
}

\author{
Mary P. Murphy \\ Department of Sociology, Maynooth University
}

\begin{abstract}
The paper examines various rationales for applying equality and human rights proofing mechanisms to fiscal policy. The principle of using available resources to the maximum to progressively realise human rights, and not to erode the revenue capacity of developing nations to do likewise, is at the heart of emerging human rights norms. To date, Irish budgetary processes and major policy statements such as the Commission on Taxation or the draft outline National Plan on Business and Human Rights Strategy have not engaged with the principles of maximising available resources or extraterritoriality. Proofing fiscal policy is also relevant from the perspective of fiscal welfare where taxation instruments, traditionally used as a revenue-gathering mechanism, are increasingly used as distributional mechanisms to achieve policy outcomes in pensions, health, housing and employment, with important equality and distributive dimensions, particularly from gender, age and socioeconomic perspectives. A number of practical institutional mechanisms and evaluative questions can guide equality and human rights proofing of fiscal policy, but commitments to maximise resources to realise rights also need to be promoted through a public discourse which sees taxation as potential investment in society rather than a burden or cost on the economy.
\end{abstract}

Keywords: Taxation, Ireland, human rights, equality, maximum available resources 


\section{Introduction}

Mechanisms to 'proof' or 'mainstream' gender, equality or poverty have traditionally focused on budgetary expenditure policy. Human rights principles observe both 'obligations of conduct', such as maximising available resources, and 'obligations of result', such as progressively realising human rights. This brings valuable attention to governments' fiscal policy and taxation choices within the world of equality and human rights, both at home and internationally.

\section{Figure 1: Economic and social rights norms and standards}

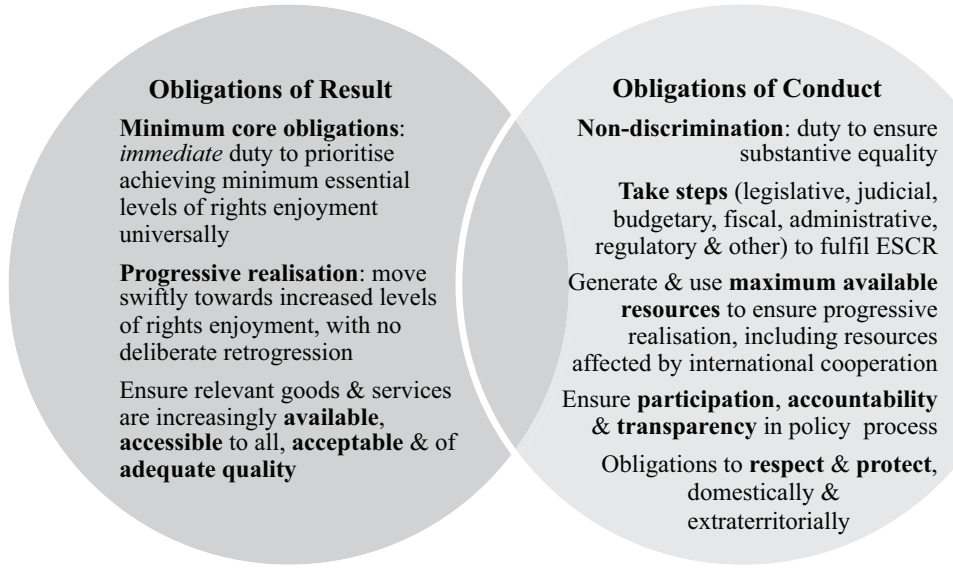

Sepúlveda-Carmona (2014, pp. 1-11) identifies 'fiscal policy, and particularly taxation policies, as a major determinant in the enjoyment of human rights', arguing that taxes, while not the only source of government revenue, are the most important. Their importance derives from the fact that taxes combine the functions of (a) generating revenue to realise rights, (b) achieving equality and tackling discrimination, and (c) strengthening governance and accountability (Saiz, 2013). Despite this, taxation policy is frequently neglected in wider policy analysis. Boden et al. (2010) locate taxation policy within an understanding of the operation of power and political choices, and position tax matters as an aspect of the social contract between the state and citizens. Figure 1 outlines a number of human rights principles, while Figure 1 in the 'Note from the Guest Editor' in this special issue, by Murphy, outlines the full range of human rights principles and O'Connell, also in this issue, outlines how such 
principles can be applied to policy proofing. This article focuses on just two human rights principles - maximising available resources and extraterritoriality - principles that are largely absent from contemporary Irish taxation policy development or evaluation.

This short paper explores the value of equality and human rights proofing mechanisms in framing fiscal policy, and briefly assesses Ireland's compliance with this norm. I first examine the principle of maximising available resources, as developed in human rights literature and practice. Secondly, and closely related, I examine the maximising available resources principle in the context of austerity and fiscal pressure, and in particular the development, in International Covenant on Economic, Social and Cultural Rights (ICESCR) General Comment No. 19 (CESCR, 2008, para 42), of principles for monitoring retrogression. Thirdly, I consider the principle of extraterritoriality and the human rights norm of protecting the revenue-raising capacity of developing nations, and review the treatment of this principle in Ireland's outline National Plan on Business and Human Rights Strategy (Department of Foreign Affairs and Trade, 2015). While traditionally revenue-raising mechanisms, taxation instruments are increasingly used as mechanisms to achieve distributional outcomes in pensions, health, housing and employment policy; hence, I then examine fiscal policy from this fiscal welfare perspective. Equality dimensions are then considered, paying particular attention to the overall incidence of taxation across deciles and the gender dynamics of taxation, both as revenue-raising and distribution mechanisms. The final section advances OPERA as a practical fiscal proofing mechanism and, using questions posed in OPERA as a starting point, poses evaluative questions to guide equality and human rights proofing of fiscal policy. I conclude by stressing the need for an institutional framework to advance the application of human rights norms to fiscal policy, the role different actors might play in achieving this and how proofing might promote a positive public discourse on taxation and human rights.

\section{Maximising available resources}

Each State Party to the present Covenant undertakes to take steps, individually and through international assistance and cooperation, especially economic and technical, to the maximum of its available resources, with a view to achieving progressively the full realization of the rights recognized in the present Covenant 
by all appropriate means, including particularly the adoption of legislative measures. (ICESCR, Article 2.1)

While there is a difference between the concepts of 'maximising available resources' and 'using available resources to the maximum', both approaches are legitimate ways to operationalise the overall human rights norms in Article 2.1 of the ICESCR. The Maastricht Guidelines on Violations of Economic, Social and Cultural Rights clarify that state parties can be considered in violation of the Covenant where they fail 'to utilize the maximum of available resources towards the full realisation of the Covenant' (Balakrishnan et al., 2011). The duty to use all available resources has several implications beyond the one I focus on here: whether, through taxation, the state could generate more resources available to it. As O'Connell explores in this issue, there are also questions as to whether the state has prioritised resources towards the realisation of rights over other projects which do not directly realise rights, or whether such resources are used, diverted to other purposes, saved and returned to the central funds. Further, the principle applies to a range of policy issues, from borrowing and debt repayment schedules to procurement and outsourcing and to whether there is an efficient use of allocated resources (Elson et al., 2013; O'Connell et al., 2014). This holistic approach is captured in the MARSTAR (see Figure 2), which depicts monetary policy, debt and deficit financing, revenue and expenditure, as well as international assistance. While the principle clearly applies to significantly more than taxation policy, our focus in this article is solely on taxation, primarily in relation to the realisation of socioeconomic rights.

Former UN Special Rapporteur on extreme poverty and human rights Magdalena Sepúlveda-Carmona identifies taxation as 'a key tool when tackling inequality and for generating the resources necessary for poverty reduction and the realization of human rights'. Acknowledging that 'promoting economic growth is also a primary and legitimate concern of State fiscal policies', she stresses that progressive taxation can help governments achieve more sustainable growth, and is clear that states do not have limitless discretion in formulating fiscal policy (2014, pp. 1-11). Current UN Special Rapporteur Philip Alston (2016) has continued to stress this dimension, highlighting the human rights obligation to ensure that fiscal policy raises sufficient revenue to tackle poverty and realise rights. 


\section{Figure 2: MARSTAR}

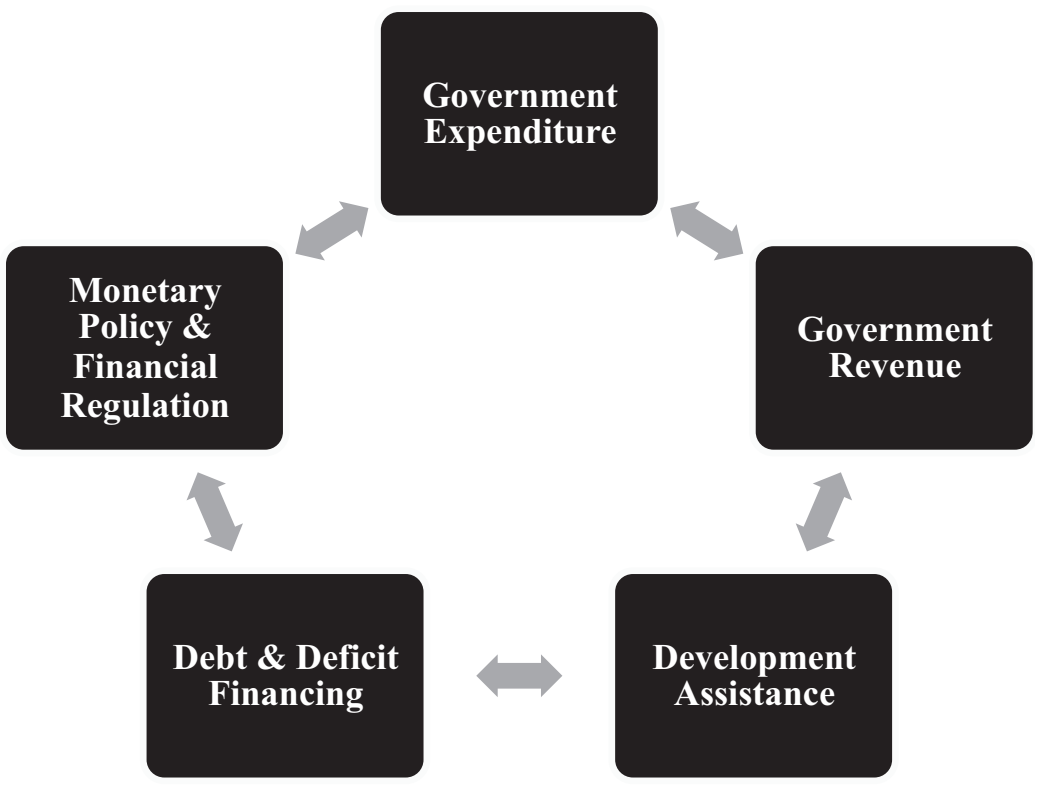

Source: Balakrishnan et al. (2011).

The Commission on Taxation (2009), in discussing international obligations and EU treaties and directives, is clear that these take precedence over domestic law. However, no reference is made to the obligation to maximise available resources when discussing Ireland's international taxation obligations. Human rights are only mentioned in the context of the European Convention on Human Rights, and the $\mathrm{UN}$ is referred to only in the context of obligations arising from the Kyoto Protocol to the UN Convention on Climate Change.

An obvious starting point in assessing whether Ireland is maximising available resources is to assess tax as a percentage of GDP, both over time and in comparison with other relevant jurisdictions. Over time, Ireland's tax-to-GDP ratio declined from 30.8 per cent in 2000 to 28.7 per cent in 2014, and 23.6 percent in 2015. The OECD's annual Revenue Statistics report found that the tax-to-GDP ratio in Ireland decreased by 5.1 percentage points, from 28.7 per cent in 2014 to 23.6 per cent in 2015 , due to Ireland's exceptionally high GDP growth in 2015 (OECD, 2016). That this growth in GDP may be in part 
a product of transfer pricing raises the question of the appropriateness of using GDP in an Irish context. Given that Irish GDP is materially skewed through multinationals' trading activities, there are comparability issues for cross-jurisdictional analysis. In this context comparative 'per capita' national revenue data might be a second measurement; like the pattern in Figure 3, Irish per capita national revenue is lower than comparator states.

\section{Figure 3: Irish taxation as \% of GDP compared to OECD average 2000-15}

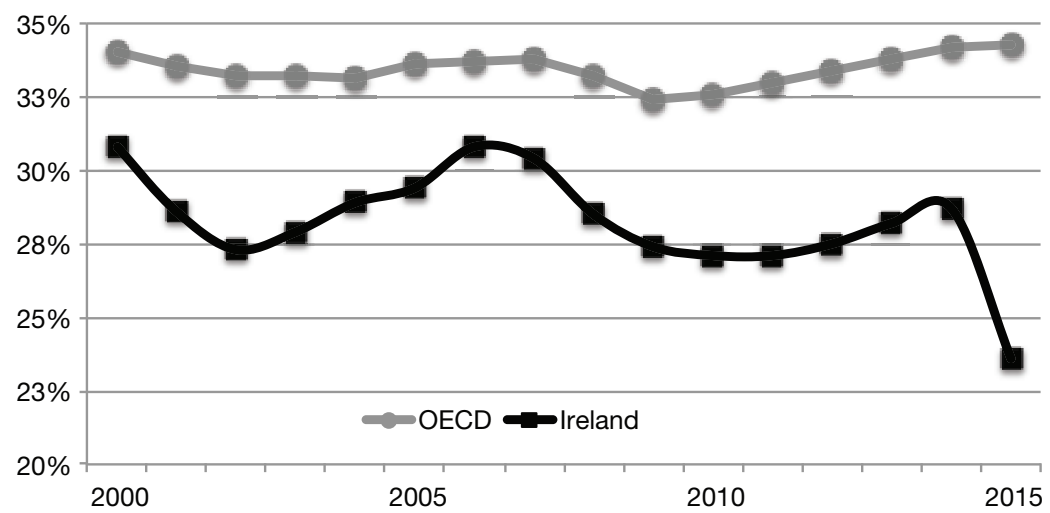

Comparatively, in 2014 Ireland ranked twenty-nine out of thirtyfive OECD countries in terms of the tax-to-GDP ratio; the OECD average was 34.3 per cent, which in turn was lower than the 40 per cent EU average and the 41.5 per cent for eurozone countries in the same year. Countries that topped the European table included France (47.9 per cent) and Denmark (47.6 per cent), followed by Belgium (47.5 per cent), Austria (44.4 per cent), Sweden (44.2 per cent), Finland (44.1 per cent) and Italy (43.5 per cent).

Alston (2016) underscores the explicit political choices underlying such taxation outcomes and stresses the potential to increase transparency and accountability. Fiscal analysis can reveal the choices political and other elites make when they forgo the opportunity and capacity to progressively realise rights by failing to raise adequate revenue. Ireland has maintained a relatively low tax burden as a core element of competition policy; that this is an explicit political choice is evident in the framing of the Commission on Taxation. The 
commission was established in 2008 to review the structure, efficiency and appropriateness of the Irish taxation system; its terms of reference included guidance to 'keep the overall tax burden low' and a 'guarantee that the 12.5 per cent corporation tax rate will remain' (Commission on Taxation, 2009, p. 35). This guidance was interpreted as implying that the net effect of all recommendations should be to maintain revenue as a constant (and relatively low) proportion of GDP: a clear policy not to maximise available resources.

\section{Maximising available resources in the context of austerity and fiscal pressures}

Until recently, guidance from UN bodies did not specifically address the challenges governments face during periods of fiscal deficit or pressure. However, in the context of the recent economic crisis, the UN Committee on Economic, Social and Cultural Rights (CESCR) developed principles for governance during times of austerity. By 2012 a series of advice had been developed to guide governments under fiscal pressure or deficit; this advice advances the principle of exploring all available alternatives to avoid human rights retrogression (Nolan, 2014). The Council of Europe Commissioner for Human Rights (2013) also issued recommendations as to how to safeguard rights in times of economic crisis. Human rights informed approaches to economic recessions engage a number of the ICESCR principles: avoiding retrogression, providing reasonable justification, examining alternatives (including fiscal alternatives), genuine participation, nondiscrimination, sustained impact, realising rights and independent review. The discrimination indicator enables examination of the differential impact of cuts and retrogressive measures, including taxation.

Loftus \& Murphy (2014) concur with the Centre for Economic and Social Rights (CESR, 2012, p. 58), which found little application of such guidelines in administration of Irish austerity budgets:

Austerity measures implemented by the Irish State fail the test of proving that they have been introduced after the most careful consideration of all alternatives and that they are duly justified by reference to the totality of the rights provided for in the Covenant... in most cases, reasonable justification for the measures cannot be identified, nor has there been serious 
consideration of alternatives, even when they have been identified in government sponsored reports. There are substantive concerns about the discriminatory nature of many austerity reforms.

Hick (2017) assesses the nature of governments' room for manoeuvre in balancing tax increases and spending cuts to achieve deficit reduction targets. The 2010 National Recovery Plan (Government of Ireland, 2010) proposed that one-third of the required fiscal consolidation would come from tax increases and two-thirds from spending reductions. Numerous NGOs advocated for a greater contribution from the tax side, and the 2011 Irish general election saw various political parties proposing tax:expenditure ratios ranging from 3:1 to $1: 1$. The incoming Fine Gael/Labour coalition settled on a 2:1 ratio in its programme for government. This was critically evaluated by the CESR in 2012 (Saiz, 2013) and by the CESCR (2015) in the committee's Third Periodic Review, Section 11 of which expressed concern that Ireland's response to the crisis had been disproportionately focused on expenditure cuts in housing, social security, health and education, while also noting cuts had been implemented without a comprehensive and human rights based review of fiscal policy.

A retrospective review of specific recession-era tax measures for their compliance with human rights principles has drawn attention to Ireland's underlying structural fiscal choices (Saiz, 2013). Relative to the OECD average, Ireland's tax structure is characterised by higher revenues from taxes on personal income, profits and gains, property and VAT; is equal to the OECD average from taxes on payroll and goods and services (excluding VAT); and has a lower proportion of revenues from taxes on corporate income and gains and social security contributions. Given the aforementioned policy approach not to increase corporate tax rates, other taxes shoulder a disproportionate burden, two of which - increased VAT and a new Universal Social Charge (USC) - have particular poverty and equality impacts. VAT is discussed briefly below, while the USC is discussed later.

As Sepúlveda-Carmona (2014, p. 12) notes, 'high tax rates for goods and services and low rates for income, wealth and property bring about inequitable and discriminatory outcomes; indeed in some instances, the negative impact of indirect taxes on the poorest can be greater than the positive effect of cash transfers'. Irish VAT is regressive, paid at the same rate by everyone regardless of income. A disproportionate 
share of a poor person's income goes to VAT, accounting for just under 30 per cent of the incomes of the poorest decile, compared to 5.6 per cent for the richest. Budget 2012 increased the standard rate of VAT (from 21 per cent to 23 per cent) without assessing the distributive impact and the composition of household contributions to VAT. Subsequent analysis found a regressive impact: losses for the bottom 70 per cent of the income distribution were above average, with the poorest decile the most affected (Collins, 2014a). At the same time the introduction of a reduced rate of VAT for the tourism sector cost almost $€ 500$ million per annum in revenue foregone; albeit an integrated impact of this policy change (positive and negative) would measure the impact of this stimulus in increasing commercial activity with related increases in corporate, income and employment tax revenue and savings from reduced unemployment.

\section{The principle of extraterritoriality}

The concept that the conduct of states may affect the human rights of individuals located outside their national territories is increasingly relevant in a globalised world, but the principle of extraterritoriality remains a highly contested principle. As no legal definitions of the main concepts involved exist, most especially the notion of 'jurisdiction', the development of this area of international law depends heavily on the criteria adopted by jurisprudence (Abrisketa \& Casas, 2016). While the concept of 'jurisdiction' under human rights law is continually evolving, recent scholarship is focused primarily on political and civil rights, where there is more case law (Milanovic, 2011), and it is accepted that there are contrary opinions as to the degree to which extraterritorial obligations extend to economic and social rights, including taxation policy. For some, however, the extraterritoriality principle means that human rights norms apply both within and beyond its territory, and that states should take action both separately and jointly, through international cooperation, to progressively realise rights. The CESR, for example, promoted the use of extraterritorial obligations to challenge the tax haven behaviour of the Swiss Government in relation to cross-border tax abuse and, with Christian Aid, argued that addressing global tax injustice is crucial to global sustainability and justice (CESR \& Christian Aid, 2014).

In February 2017 the CESCR provided greater clarity in a draft general comment on state obligations in the context of business activities (CESCR, 2017), filling an important gap in applying human 
rights law to situations of business-related rights violations. While encouraging social responsibility, the CESCR is clear that it is ultimately sovereign states - as the primary human rights duty-bearers - that set the legal and regulatory framework which either promotes or prevents corporate tax abuse; governments have a duty to protect the tax base (CESR, 2017a). The challenges that states face in effectively raising revenue have increased since the 1960s. International capital is more mobile, the number of multinational corporations continues to grow and states increasingly use taxation mechanisms to compete for international investment. Alston (2015) laments that Ireland has intentionally developed tax policies with a global reach, facilitating tax competition and avoidance, thereby contributing to a 'tax war' where many countries become embroiled in a 'race to the bottom', or, like Ireland, become tax havens. In the Apple case Ireland stands accused of developing tax mechanisms that support tax evasion through facilitating transfer mispricing. Attiya Waris (2016) illustrates how Irish double taxation treaties facilitate a significant level of tax avoidance and evasion in Africa. Ireland has concluded a significant number of double taxation treaties with other countries (forty-six in force and a further five signed), treaties that Waris associates with significant levels of fiscal evasion, and that need to be assessed for compliance with human rights. McNair et al. (2009, p. 78) identify various other tax measures that feature in Ireland's international competition model, including tax competition through special corporate rates and/or special economic zones, and special tax treatment of intellectual property rights, research and development most recently 'knowledge boxes'. Oxfam (2016) found that Ireland ranked sixth in a new league table of the world's worst corporate tax havens which help big companies avoid paying their fair share of tax while costing governments resources to invest in health, education and tackling poverty.

The 2009 Commission of Taxation made no reference to the principle of extraterritoriality but this human rights principle has been highlighted in pioneering work of various development NGOs in recent years (Christian Aid, 2016; Oxfam, 2016). In 2008 Christian Aid's first tax justice campaign made the direct link between tax avoidance and global poverty. Since then, the importance of tax justice has been increasing on the global and domestic agenda. As a global taxation player, Ireland now finds its policy under the spotlight for the degree to which it impacts on the capacity of developing countries to retain domestic profits and revenues for local taxation. In June 2014 
Ireland began the process of developing a national plan to implement the UN's Guiding Principles on Business and Human Rights. The national plan aims to support implementation of these principles by providing companies (both those operating in Ireland as well as overseas) with guidance on how to ensure respect for human rights in their activities. The Department of Foreign Affairs was encouraged, in various submissions, to focus on the degree to which Irish taxation policy had extraterritorial implications. The working outline of the plan is (at time of writing) silent on taxation policy as an aspect of Ireland's business and human rights strategy. The section reviewing the legislative and regulatory framework makes no mention of the various (now infamous) Irish tax mechanisms which have disadvantaged developing countries (Waris, 2016), as documented by a range of well-considered inputs by various NGOs, including Trócaire, Dóchas, Oxfam, Social Justice Ireland and Christian Aid.

Since publication of the outline national plan, the EU has ruled on Ireland's taxation of Apple, underscoring the significant extraterritorial implications of domestic fiscal choices. Attention to the extraterritorial impact of domestic taxation policy has had some traction, with a welcome formal spillover analysis published with Budget 2016 (Department of Finance, 2015). The report was an important step forward in spillover analysis; albeit data limitations continue to impede this kind of analysis. While there have been some proactive reforms in double taxation mechanisms, and a shift in rhetoric, overall Ireland still markets itself abroad as a low-tax regime, enabling aggressive tax avoidance and potentially depriving developing countries of much-needed revenue. Ireland also appears ambivalent in where it is situated in emerging global governance on taxation. While appearing proactive in the OECD Base Erosion and Profit Shifting (BEPS) reform process, Ireland appears to resist efforts to create a global tax body by upgrading the UN tax committee to an intergovernmental committee (Cosgrove, 2017).

\section{Fiscal welfare}

Half a century ago Titmuss (1958) distinguished three sources of welfare: social, occupational and fiscal. Analysis of state effort in realising socio-economic rights tends to focus on the welfare state and direct public provision of services, paying less attention to the distributive impacts of occupational and fiscal welfare systems (Morel et al., 2016). However, a range of welfare regimes use tax instruments 
to subsidise private pensions, health insurance and housing (both owner-occupier and private rented); various countries use the tax system to 'make work pay', while several states subsidise various household, childcare and nursing services via the tax system. The growing salience of fiscal welfare points to the importance of assessing both the degree to which such policy choices progressively realise rights and/or discriminate against particular groups, as well as the degree to which they impact on the goal of maximising available resources: tax reliefs represent revenue foregone. Fiscal welfare potentially incurs maldistribution: only certain demographics have potential to utilise tax credits, so their use has strong equality patterns in terms of gender, age and class. The Irish Commission on Taxation (2009) considered the increased use of tax expenditures applying across a range of policy areas, and documented those tax credits acting as a form of income support. To illustrate further, I sketch three tax policies with gender and socio-economic implications, as well as potential relevance across all equality grounds, albeit no fiscal measure was equality proofed.

From January 2014 a new Single Person Child Carer Credit (SPCCC) replaced the One Parent Family Payment tax relief. Both sought to relieve the tax burden on single-parent families, so that the tax paid on equivalent income was more in line with that paid by a married couple rather than a single person. In 2012 it was estimated that 75,800 parents claimed the credit, at an annual cost of $€ 124$ million. The key change under the SPCCC is that only one carer can claim the credit (the primary carer can 'surrender' their entitlement to the credit to the secondary carer), whereas previously both the primary and non-resident parent were eligible. There has been no human rights or equality assessment of the change.

Budget 2009 introduced the USC - a significant change to the Irish tax system, and a new charge on gross incomes - without any formal human rights and equality analysis. While the rates and thresholds for the USC have been amended over subsequent budgets, when first introduced the highest rate applied to wages barely above the level of the national minimum. Accordingly, women - over-represented in low-paid employment - were significantly impacted. The USC is charged on gross income, including pension contributions. Households covered by a medical card, often exempt from such levies and taxes in Ireland, are not exempted in relation to the USC. Ex post USC assessments by Barry \& Conroy (2013) and Collins (2016) have shown significant gender and socio-economic maldistribution. This is 
not an argument against the USC, which can be seen as part of a progressive strategy to maximise available resources; rather it is an argument for timely, thorough and public 'proofing' of fiscal policies. A human rights and equality analysis should also be applied to proposals to abolish the USC, a proposal with obvious impact on maximum available resources.

Dukelow \& Murphy (2016, p. 21) argue that the extent of Irish fiscalisation - administration of welfare through the tax system remains a relatively hidden feature of the Irish welfare state. Analysis of tax relief on private pension contributions illustrates the regressive impact such measures can have. Tax relief on private pension contributions from employers, employees and individuals, as well as on the investment income of pension funds, accounts for up to $€ 2.4$ billion in revenue foregone to the state. Most contributors who benefit from tax relief at the higher marginal rate (40 per cent) pay tax in retirement at the standard rate ( 20 per cent) because their taxable income in retirement is likely to be only half or less of their preretirement income. From a distributional perspective the main beneficiaries of the private pension system are high earners, almost all of whom have pension coverage and who can benefit most from marginal tax reliefs for pensions (Hughes \& Collins, 2016) (see Figure 4). The gendered distribution of high earnings in Ireland means that the $€ 2.4$ billion tax expenditure on pension tax relief is strongly skewed towards male recipients.

Figure 4: Distribution of tax relief by income decile

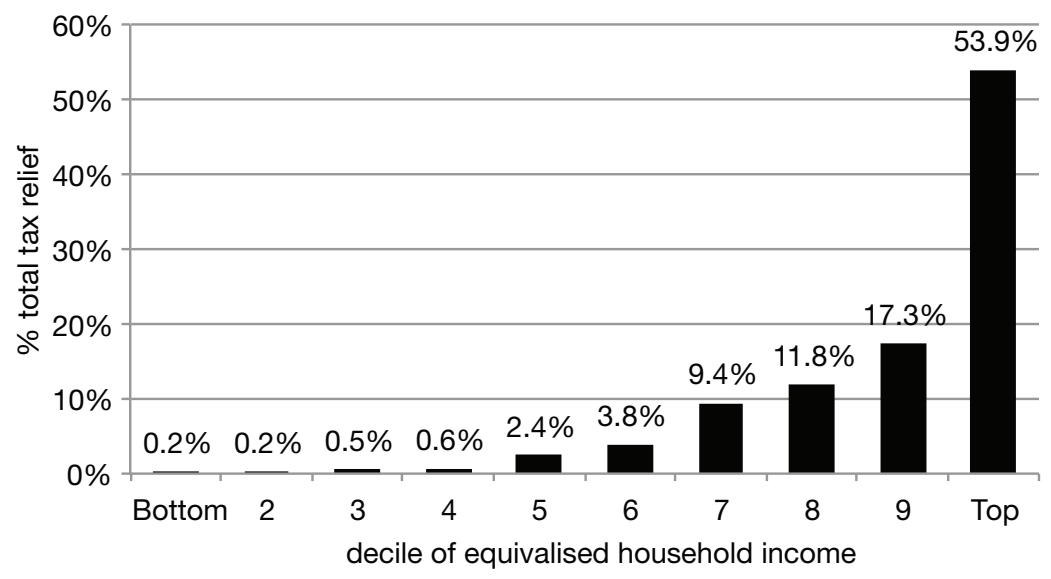




\section{Equality dimensions of taxation}

'Taxation has the potential to redress systemic discrimination... and to spur progress towards substantive equality but achieving this outcome requires very careful design' (Sepúlveda-Carmona, 2014, p. 12). Indeed Nacpil (2015) draws attention to potentially negative distributional, equality and gendered consequences of fiscal policy. Collins (2014b) establishes an important baseline in understanding the distributional features of Ireland's total tax contribution distribution. Figure 5 assesses the incidence of total personal direct and indirect income, and illustrates how, across the income distribution, three deciles contribute taxation to the exchequer at above the average level - the top two deciles and the bottom decile, the latter decile primarily through indirect taxation.

Figure 5: Total household tax contributions, \% gross income (equivalised data national scale)

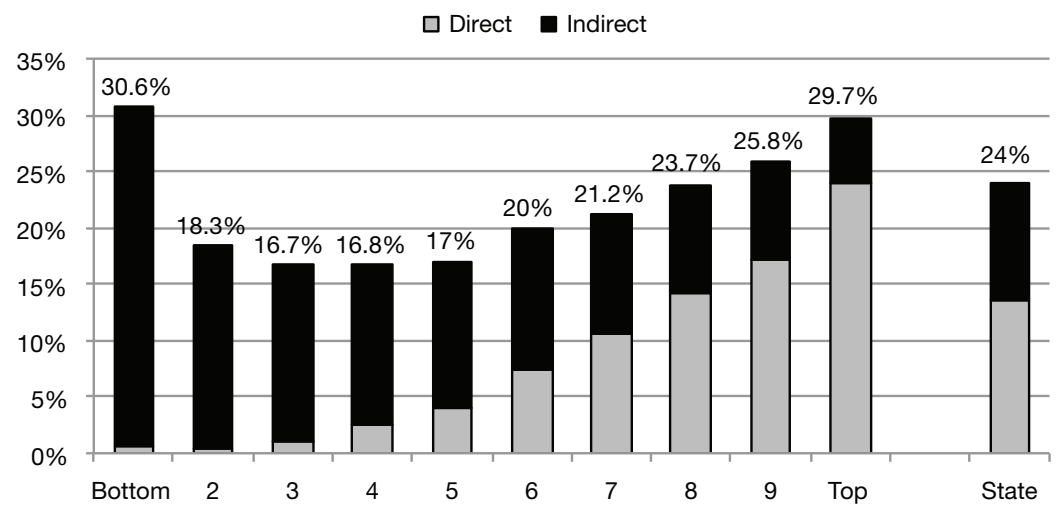

Killian (2015) explored the practicality of applying equality budgeting to Irish taxation policy, extrapolating lessons from gender budgeting to the other eight equality grounds protected under Irish law (age, disability, civil status, family status, sexual orientation, race, religion and membership of the Travelling community). She examined the real and perceived impact of recent Irish tax policy through direct analysis of specific measures, and through interviews with advocacy groups. In general, she found that advocacy groups and policymakers paid insufficient attention to the potential equality impacts of tax policy. Her direct analysis, predicated on the principle of 'first do no 
harm', found that while relatively few recent tax measures specifically impacted on a dimension of inequality, intersectional considerations where tax measures impact more than one group at once - were important. Table 1 outlines a range of taxation issues over the equality grounds (Killian, 2015).

Table 1: Equality grounds and taxation issues

\begin{tabular}{ll}
\hline Ground & Tax issues \\
\hline Gender & VAT anomalies - children's clothing and shoes, books and e- \\
& $\begin{array}{l}\text { books, personal care products for women; taxability of } \\
\text { maternity payments; balance of tax revenue; lack of tax relief } \\
\text { for childcare; regressive USC; changes to tax and benefits for } \\
\text { lone parents }\end{array}$
\end{tabular}

Marital status Tax measures to alleviate hardship in the case of widows and widowers, following a bereavement; changes to tax and benefits for lone parents; divorce- and separation-related taxation issues

Family status Child tax issues; dependent relatives; focus more on government expenditure than taxation

Sexual No outstanding anomalies since the passing of the marriage orientation equality referendum

Race Double tax issues for migrant workers in Ireland, particularly those coming from countries with which Ireland does not have a double tax deal; favourable specific tax breaks for high net worth and key employees; and other rules which could have an indirect adverse effect

Religion Affording of charitable status to bodies engaged in this work might be argued to confer an advantage on some religious groups

Disability VAT refunds on some health aids and appliances; refund of VRT on a specially adapted vehicle; VAT inconsistencies around products used by people with disabilities; reduction of specific tax credits, including Blind Tax Credit, Incapacitated Child Credit and Home Carer Credit

Travellers Travellers who live on halting sites are exempt from property taxes, and are also unable to avail of property-related incentives such as Home Renovation Schemes, etc.; arguably, the property-based focus of much of our recent income tax legislation excludes most Travellers 
Table 1: Equality grounds and taxation issues (contd.)

\begin{tabular}{ll}
\hline Ground & Tax issues \\
\hline Age & $\begin{array}{l}\text { Income tax relief on pensions and medical expenses; } \\
\text { income-based exemptions for water and property taxes and } \\
\text { carbon taxes on winter fuels; VAT inconsistencies that } \\
\text { impact only on the elderly (incontinence pads, walking } \\
\text { sticks, geriatric chairs are rated at 23 per cent, etc.); } \\
\text { anomalies around home adaptation; different } \\
\text { older/younger allowable pension contributions; capital } \\
\text { gains and capital acquisitions taxes differently incentivise } \\
\text { the passing on of assets from the older to the younger } \\
\text { generations; VAT issues which apply to children's clothes } \\
\text { (children's clothes zero rated only to specific size - primary }\end{array}$ \\
$\begin{array}{l}\text { schoolchildren) } \\
\text { Intersectional }\end{array}$ & $\begin{array}{l}\text { Reliefs by way of tax credit can only be availed of by } \\
\text { people earning enough to pay tax; taxes at marginal rate } \\
\text { issues and } \\
\text { socio-economic } \\
\text { status }\end{array}$ \\
& $\begin{array}{l}\text { are more beneficial to higher earners; absence of } \\
\text { refundable tax credits means tax reliefs cannot fully benefit }\end{array}$ \\
\hline low-income earners
\end{tabular}

Source: Killian (2016, Appendix A).

\section{Tools, mechanisms and evaluative questions}

A number of specific tools, mechanisms and frameworks can assist in proofing fiscal policy. For reasons of space I review only one 'OPERA' - a four-dimensional framework to monitor economic, social and cultural rights developed by the CESR (see Figure 6). Building on OPERA, I then outline a series of evaluative questions to guide development of human rights and equality proofing mechanisms for Irish fiscal policy.

OPERA focuses on the four dimensions of policy: Outcomes, Policy Effort, Resource generation and allocation, and an Assessment of the context influencing the state's level of compliance with human rights obligations. The human rights principles of progressive realisation, maximum available resources and non-discrimination are evaluated in Stage 3 of the OPERA framework. Specific questions are applied to resource evaluation: (a) calculate the state budget as a percentage of the overall economy, (b) compare to other countries, (c) identify the adequacy and equity of the state's main revenue sources (taxation, borrowing), (d) identify the state's tax base as percentage of GDP, (e) track its evolution over time (taking into account context and economic growth). 
Figure 6: OPERA four-dimensional ESCR monitoring framework

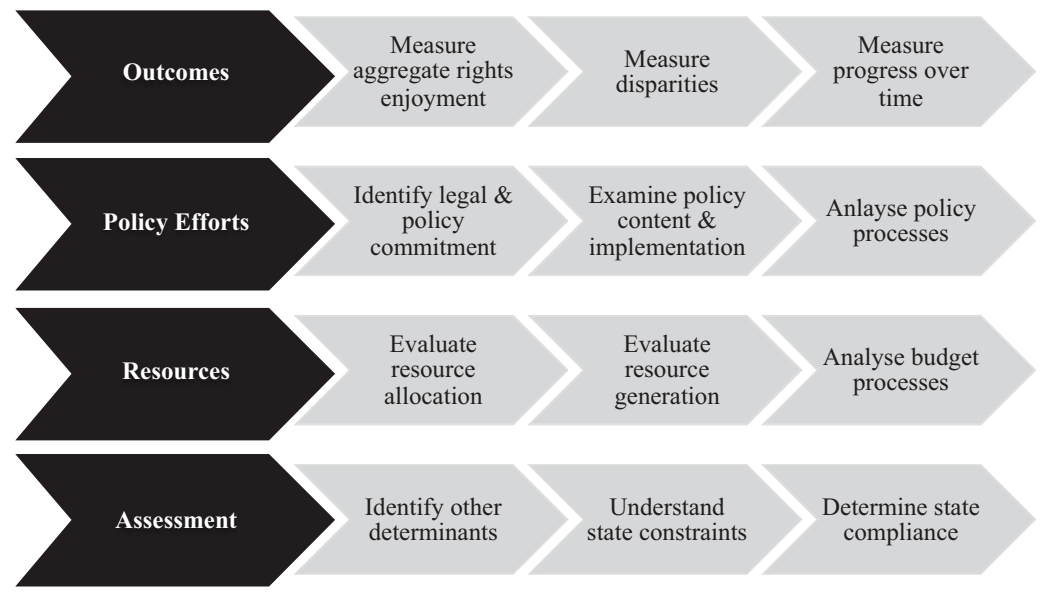

Source: www.cesr.org

Saiz (2013) illustrated, through a case study of the application of the OPERA mechanism to Guatemala, how human rights advocates successfully combined human rights instruments with evidence to shift the national discourse on taxation away from an ideological debate and towards one that exposed the impact of political choices about taxation and their impact on people's and citizens' lives. Such evidence is of use to various actors, domestic human rights advocates, political parties and UN bodies in their efforts to reframe how government choices are understood. A 2017 retrospective application of OPERA to Ireland's crisis budgets concluded that governments prioritised deep social spending cuts over revenue-generating reforms to an unjust and regressive taxation system (CESR, 2017b, p. 3). Inspired by the questions posed in OPERA, I now outline a series of practical, evaluative questions, which serve as prompts to guide the application of human rights principles to Irish fiscal policy:

- What is the state budget as a percentage of the overall economy and how does this compare to other countries and across time?

- What are the state's main revenue sources (taxation, borrowing) and what revenue goal could Ireland adopt as part of a strategy to maximise available resources?

- What data are needed to adequately assess the distributional impact of fiscal policy across the nine equality grounds and socioeconomic grounds? 
- What implications does the household-based Irish income tax system have for realisation of individual rights?

- What type of taxation choices would maximise realisation of human rights and equality? To what degree has government adequately explored alternatives and enabled other elements of public administration to debate and decide these alternatives?

- How can we make an overall assessment of fiscal progressivity? Which equality grounds and issues can be considered in the formation of tax policy?

- What type of tax choices should be avoided to ensure no negative impact on human rights and equality? Are some fiscal choices more regressive than others? How can regressivity be tracked, including new regressive costs/charges/user taxes?

- What specific sectoral tax justice issues need to be addressed, e.g. pensions, employment, housing, health, in-work benefits?

- Are fiscal and expenditure policies treated as silos or assessed in an integrated human rights and equality frame? Is there sufficient capacity to proof dynamic integrated impacts of policy changes?

- What is the status of international obligations vis-à-vis international donor treaties? Is Irish policy regarding Common Consolidated Corporate Tax Bases and BEPS compliant with human rights and equality principles?

\section{Conclusion}

Traditionally, human rights culture, acknowledging the state's wide margin of discretion, has avoided examination of politically contentious taxation policy. International experience of proofing, reviewed in this special issue and elsewhere, suggests proofing expenditure can be of considerable value, not least in raising the profile of policy choices and increasing the transparency of decisions. This same logic applies to proofing fiscal policy from the perspective of equality and human rights. Gendering this discourse may be useful in generating consensus about strategies to develop a sense of solidarity and interdependence and a 'politics of the common good' (Vail, 2010). Cosgrove (2017) and Collins (2016) draw a clear line connecting taxation and social policy, explicitly making links between tax revenues, public services, poverty reduction and good governance, and ultimately building the Irish case for taxability (Dukelow \& Murphy, 2016). Setting Irish goals and targets for the contribution that fiscal policy can make to maximising resources would be a positive step 
that could be monitored and tracked through an annual proofing process.

What institutional arrangements are necessary to advance the application of human rights principles in Irish fiscal policy? The Irish budget process is evolving and improving in transparency but much of the institutional innovation in the Irish budget process has taken place on the public expenditure side, with less engagement with proofing of fiscal policy by the Department of Finance. That said, some institutional processes are emerging or advancing, including more use of ex ante distributional analysis of taxation measures and greater engagement with parliamentary budget scrutiny processes and parliamentary committees. An important new institutional actor is the new independent Irish Parliamentary Budget Office, to be established in 2017. An immediate and welcome benefit of merging equality and human rights institutions, as occurred with the creation of the Irish Human Rights and Equality Commission (IHREC), is the merging of concern for distributional equality with economic and social rights. The IHREC has a potentially valuable role to play in holding government to account for fiscal policy and taxation choices within the world of equality and human rights, both at home and internationally.

Consultation and participation, along with transparency and accountability, are core features of good governance informed by a commitment to human rights. In her assessment of equality and fiscal policy, Killian (2015) welcomes recent greater engagement by both development and domestic NGOs, as well as the public more broadly, in fiscal policy discourse. She notes the need for established actors to accommodate, rather than ignore, these relatively new voices, but observes that 'many advocacy groups felt constrained in influencing tax policy by their own lack of tax expertise, and a lack of direct access to tax policy-makers'. Contrasting the ability of industry groups to influence or inform tax policy formation with the ability of equality NGOs, Killian concludes that there 'there is a question about effective consultation and how time-consuming it is, and whether civil society organisations are resourced to do it or not' (Killian, 2015, p. 7). Stakeholder engagement can be accommodated domestically through Ireland's traditional pre-budget submission processes and National Economic Dialogue events, and internationally through participation in the Addis Tax Initiative and emerging global tax governance processes. Institutions such as the IHREC can resource capacity building of civil society to create demand for, and to promote the use of, fiscal proofing mechanisms. 
Robertson (1994, p. 694) notes the general hostility to tax increases and how less-trusting citizens need to be convinced that such investment does build social and economic cohesion which ultimately benefits all. A human rights framework can provide good governance to ensure reasonable and proportional policy and accountable governments. Proofing fiscal policy can educate society and enable a national discourse that frames taxation as an investment in human rights, rather than a cost or burden on economy and society, building public support for a more progressive system.

\section{References}

Abrisketa, J., \& Casas, M. (2016). Extraterritorial application of human rights treaties. Retrieved from http://www.oxfordbibliographies.com/ view/document/obo-9780199796953/obo-9780199796953-0136.xml [10 July 2017].

Alston, P. (2015, February 12). Tax policy is human rights policy: The Irish debate. Keynote address, Christian Aid Ireland conference, Dublin.

Alston, P. (2016, December 16). Rethinking economic policy for social justice: The radical potential of human rights. Keynote address, London School of Economics conference, London.

Balakrishnan, R., Elson, D., Heintz, J. \& Lusiani, N. (2011). Maximum available resources \& human rights: Analytical report. New Jersey: Rutgers, CWGL.

Barry, U., \& Conroy, P. (2013). Ireland in crisis 2008-2012: Women, austerity and inequality. In J. Rubery \& M. Karamessini (Eds), Women and austerity - The economic crisis and the future for gender equality (pp. 186-206). London: Routledge.

Boden, R., Killian, S., Mulligan, E., \& Oats, L. (2010). Critical perspectives on taxation. Critical Perspectives on Accounting, 21, 541-44.

CESCR. (2008). General comment No. 19. The right to social security (Art. 9) [E/C.12/GC/19]. Geneva: UN.

CESCR. (2015). Concluding observations on the Ireland's third periodic review [E/C.12/IRL/CO/3]. Geneva: UN.

CESCR. (2017). General comment on state obligations under the International Covenant on Economic, Social and Cultural Rights in the context of business activities [E/C.12/60/R.1]. Geneva: UN.

CESR. (2012). Mauled by the Celtic Tiger. Madrid: CESR.

CESR. (2017a). Corporate taxation key to protecting human rights in the global economy. Retrieved from http://www.cesr.org/corporate-taxation-keyprotecting-human-rights-global-economy [11 July 2017].

CESR. (2017b). OPERA in practice: Human rights in Ireland's economic meltdown. NY: CESR. 
CESR \& Christian Aid. (2014). A post-2015 fiscal revolution: Human rights policy brief. NY: CESR.

Christian Aid. (2016). A report on the Christian Aid seminar on the human rights implications of tax and fiscal policy. Dublin: Christian Aid.

Collins, M. L. (2014a). The distributive effects of recent VAT changes in the Republic of Ireland [NERI WP 2014/No. 19]. Dublin: Nevin Economic Research Institute.

Collins, M. L. (2014b). Total direct and indirect tax contributions of households in Ireland: Estimates and policy simulations [NERI WP 2014/No. 18]. Dublin: Nevin Economic Research Institute.

Collins, M. L. (2016). Ireland's income taxation system: A social policy perspective. In G. Tobin \& C. O'Brien (Eds), Irish tax policy in perspective. Dublin: Institute of Taxation and Department of Finance.

Commission on Taxation. (2009). Commission on Taxation report 2009. Dublin: The Stationery Office.

Cosgrove, M. (2017). On corporate tax, fairness, responsibility and leadership. Retrieved from https://businesshumanrightsireland. wordpress.com/2017/ 02/23/guest-post-mary-cosgrove-on-corporate-tax-fairness-responsibilityand-leadership/ [7 July 2017].

Council of Europe Commissioner for Human Rights. (2013). Safeguarding rights in times of economic crisis. Geneva: Council of Europe.

Department of Finance. (2015). IBFD spillover analysis possible effects of the Irish tax system on developing economies, July 2015. Dublin: Department of Finance.

Department of Foreign Affairs and Trade. (2015). National plan on business and human rights strategy draft outline. Dublin: Department of Foreign Affairs and Trade.

Dukelow, F., \& Murphy, M. P. (2016). Welfare states: How they change and why. In M. P. Murphy \& F. Dukelow (Eds), The Irish welfare state in the twenty-first century: Challenges and change. London: Palgrave.

Elson, D., Balakrishnan, R., \& Heintz J. (2013). Public finance, maximum available resources and human rights. In A. Nolan, R. O'Connell \& C. Harvey (Eds), Human rights and public finance. London: Hart.

Government of Ireland. (2010). The national recovery plan 2011-2014. Dublin: The Stationery Office.

Hick, R. (2017). Enter the troika: The politics of social security during Ireland's bailout. Journal of Social Policy. Advance online publication. doi: 10.1017/S0047279417000095

Hughes, G., \& Collins, M. (2016). Tax expenditure on occupational pensions in Ireland: Relevance, cost \& distribution. Dublin: Pensions Policy Research Group, Trinity College Dublin.

Killian, S. (2015). Equality budgeting in Ireland: A tax-based exploration. Dublin: Institute of Certified Accountants.

Loftus, C. \& Murphy, M. P. (2014) A gendered right to social security and decent work? The debate in the context of Irish austerity. In B. Goldblatt 
\& L. Lamarche (Eds), Women's right to social security (pp. 239-62). London: Hart.

McNair, D., Killian, S., Collison, M., \& Cumming, M. (2009). Tax justice: The impact of global tax on developing countries and the role Ireland can play. Trocaire Development Review Dublin, 25, 77-96.

Milanovic, M. (2011). Extraterritorial application of human rights treaties: Law, principles, and policy. Oxford: Oxford University Press.

Morel, N., Touzet, C., \& Zemmour, M. (2016). Fiscal welfare and welfare state reform: A research agenda [LIEPP working paper, February 2016, No. 45]. Paris: Sciences Po.

Nacpil, L. (2015, February 12). Tax justice in Asia. Paper presented to the Christian Aid Conference, Dublin.

Nolan, A. (2014). Putting ESR-based budget analysis into practice: Addressing conceptual challenges. In A. Nolan, R. O'Connell \& C. Harvey (Eds), Human rights and public finance (pp. 41-59). London: Hart.

O'Connell, R., Nolan, A., Harvey, C., Dutschke M., \& Rooney E. (2014). Applying an international human rights framework to state budget allocations: Rights and resources. London: Routledge.

OECD. (2016). Revenue statistics 2016 - Ireland. Retrieved from https://www.oecd.org/tax/revenue-statistics-ireland.pdf [10 July 2017].

Oxfam. (2016). Tax battles: The dangerous global race to the bottom on corporate tax. Dublin: Oxfam Ireland.

Robertson, R.E. (1994). Measuring state compliance with the obligation to devote the 'maximum available resources' to realizing economic, social, and cultural rights. Human Rights Quarterly, 16 (4), 693-714.

Saiz, I. (2013). Resourcing rights: Combatting tax injustice from a human rights perspective. In A. Nolan, R. O'Connell \& C. Harvey (Eds), Human rights and public finance. London: Hart.

Sepúlveda-Carmona, M. (2014). UN Special Rapporteur on Extreme Poverty and Human Rights report 2014. Geneva: UN.

Titmuss, R. (1958). Essays on the welfare state. London: George Allen \& Unwin.

Vail, J. (2010). Decommodification and egalitarian political economy. Politics and Society, 38 (3), 310-46.

Waris, A. (2016, October 26). Apple tax: What are the global implications? Paper presented at Christian Aid Seminar, European Parliament Buildings, Dublin 2. 